\title{
Studies on Exposure Time for Freeze Branding using Copper and Brass Metal in Sahiwal Cattle
}

\author{
Arvind K. Nandanwar ${ }^{1}$, Sharad Mishra ${ }^{2}$ and Deepak Thakur ${ }^{3}$ \\ ${ }^{1}$ KVK, Mahasamund, IGKV, Raipur, India \\ ${ }^{2}$ LPM, College of Veterinary Sciences \& Animal Husbandry, CGKV, Durg, India \\ ${ }^{3} \mathrm{KVK}$, Balod, IGKV, Raipur, India \\ *Corresponding author
}

\section{Keywords}

Brass, Copper,

Freeze branding,

Exposure time, Age

group, Sahiwal

cattle

Article Info

Accepted:

04 November 2019

Available Online:

10 December 2019
The present investigation was conducted at the Bull Mother Experimental Farm, College of Veterinary Science \& A.H., Anjora, Durg. Age group of Sahiwal cattle 0 to 6 and 6 to 12 months, the days required for appearance of white hairs was relatively lesser ( $43.33 \pm 1.20$ and $42.8 \pm 4.93$ days) at 7 and 8 seconds, respectively for copper metal during freeze branding. In $12-18$ months of age group, minimum days (55.5 \pm 6.54$)$ required for appearance of white hairs were seen at 18 seconds of exposure time using brass metal. The 100 percent legibility of white hairs in 0 to 6 months of age group for copper metal, whereas, age group of 6 to 12 months, the 100 percent legibility of white hairs was seen for both the metals. The weak legibility of white hairs was seen in above 18 months of age group which can be attributed to the thickness of skin of animals which may have become thicker with advancement of age. Brass metal was better than copper metal as 5 per cent animals scored 5 . Hence, on the basis of score points, it was concluded that brass metal is better for all age group over copper metal. The mean value of neutrophils, before and after freeze branding, was $20.28 \pm 1.62$ and $22.62 \pm 2.47 \%$, respectively within the normal range and could not be an indication of stress associated with freeze branding.

\section{Introduction}

Proper identification of animals is a key of record keeping leading to improve management of a herd. Identification of animal in livestock enterprise is of immense importance to draw conclusion of their status in production as well as performance. Individual animal identification will allow producers to keep records of an animal's parentage, birth rate, production records, health history, to keep a watch on animals expected to be in heat on a given day, to dry off, to cull to perform AI and to get other important management information required to study status of farm. Marking of cattle for identification should involve methods that are easy to read at a distance, easy to apply, 
permanent, durable and economic. There are several methods in vogue to identify the animal though none of them is flawless and foolproof (Mishra et al., 2005). The several methods of identification, freeze branding is a method of livestock identification, which is less stressful to animals (Lay et al., 1990) and has been accepted widely in developed countries. Freeze branding offers a permanent form of identification i.e. easy to read at a greater distance, cause minimal damage to the hide and is less painful than hot branding (Lay et al., 1992 and Schwartzkopf-Genswein et al., 1997). This method resulted in destruction of pigment cells resulting in a white haired patch on the skin of Sahiwal. The Sahiwal is one of the best dairy breeds in India. The colour of Sahiwal is red. The white hair appearing on the skin will be permanent and remain easily readable. The present study was designed to observe the best exposure time of copper and brass metal for effectiveness of freeze branding.

\section{Materials and Methods}

Present study was conducted on 80 Sahiwal cattle of different age groups at the Bull Mother Experimental Farm, College of Veterinary Science \& A.H., Anjora, Durg. Each group comprised of 20 animals (Table 1). The age of animals ranged from 0 month to above 18 months (Hall et al., 2004). The branding metal (copper and brass) is an important instrument which acts as a medium to expose the required temperature to the skin of animals whereas, by various workers (Farrell et al., 1966 and Whitter et al.,1993) assessed copper metal but present studies on freeze branding comparison with brass metal. The shape of metal was moulded to "I" shape and the width and depth (face to back) of metal brand are same for all age group of animals where as length and weight was different on the basis of age group of animals (Bath et al., 1981). The liquid nitrogen was used as refrigerant. The temperature of it is nearly to $-196^{\circ} \mathrm{C}$ and remains as liquid in that temperature (Key et al., 1977 and Wagner et al., 2000). The frosted branding metal was quickly applied on the skin of the cattle with firm pressure by holding the metal on the area and do not let it slip. Freeze branding experiment conducted mostly on exotic breed but there is no evidence for the indigenous breed i.e. Sahiwal, as well as no evidence of exposure time for freeze branding in Sahiwal, so we observe appearance of white hairs, legibility of white hairs, scoring system (Table 2) for selection of metal at different exposure times for different age groups (Farrell and Potter, 1966, Hall et al., 2004, Hooven et al., 1971 and McMahon et al., 2006) and also find haematological parameter were recorded to observe the stress occurred due to this method. To see the effectiveness of branding by different exposure times in different age groups one way analysis of variance was applied (Snedecor and Cochran, 1994) and any significant difference exist in any group then DMRT was applied (Steel and Torrie, 1984).

\section{Results and Discussion}

\section{Appearance of white hairs}

In 0-6 months age group, the average time for appearance of white hairs on the skin in present investigation was found to be $45.6 \pm 1.96$ and $50.93 \pm 1.3$ days for copper and brass metals, respectively (Table 3 ). The minimum and maximum time being $43.33 \pm 1.20$ and $55.25 \pm 1.75$ days, respectively. Relatively, lesser time was seen for the appearance of white hairs at 7 to 9 seconds (43.33 \pm 1.20 and $43.4 \pm 4.26$ days respectively) using copper metal. However all the values were non-significantly different with respect to both metals and exposure times used in present studies. Similar results were found by Sherwin et al., (2002) (Fig. 1). 
In 6-12 months category an average time of $48.33 \pm 2.46$ and $50.2 \pm 1.42$ days, respectively for copper and brass metal were observed for appearance of white hairs on skin following freezing (Table 3). The minimum and maximum days required for appearance of white hairs were $42.8 \pm 4.93$ and $58 \pm 2.08$ days respectively. However, these results were in agreement with the findings of Bath et al., (1981) and Bertram et al., (2006), where they observe 6 weeks for the appearance of white hairs growth.

In Sahiwal, the average time for appearance of white hairs on skin were $58.09 \pm 1.34$ and $58.9 \pm 2.44$ days, respectively for copper and brass metal (Table 3) with minimum and maximum days being $55.5 \pm 6.54$ and $62.5 \pm 2.5$ days, respectively in 12-18 months category. In this age group, minimum of $55.5 \pm 6.54$ days required for appearance of white hairs were seen at 18 seconds of exposure time using brass metal. However, all the values did not differ significantly with respect to all exposure time and metals used in present investigation of 12 to 18 months age group. Similar findings were observed by Bath et al., (1981) and Bertram et al., (2006).

Above 18 months of age group, the average time of appearance of white hairs on skin were $58 \pm 2.32$ and $58.7 \pm 2.56$ days, respectively for copper and brass metal (Table 3). However, the minimum and maximum values for appearance of white hairs varied from $47 \pm 00$ to $64 \pm 2.0$ days for all types of metal. The difference in the time required for appearance of white hairs in all exposure time of above 18 months age groups of copper and brass metals were non-significant. These findings were in accordance with the findings of Sherwin et al., (2002). Overall, a trend was noticed that relatively more days were required for appearance of white hairs with the advancement of age.

\section{Legibility of freeze brand}

In 0-6 month's category, the legibility of white hairs for copper metal varies from 60 to 100 per cent. For brass metal the legibility varies from 60 to 80 per cent inspite of nonsignificant difference $\left(\chi^{2}=0.798\right)$ among them (Table 4). However, the chi-square value indicated non-significant difference between the legibility of white hairs and various exposure times. Although 100 per cent legibility was observed in 9 and 7 seconds of exposure time using copper whereas 80 per cent legibility was observed in 5,9 and 11 seconds of exposure time using brass metal is also acceptable.

In 6-12 months of age group, the legibility of white hairs for copper metal varied from 60 to 100 per cent. In case of brass the legibility varied from 60 to 100 per cent, in spite of this no significant difference $\left(\chi^{2}=2.5\right)$ among them was noticed (Table 5). In copper metal, the chi-square value $\left(\chi^{2}=2.932\right)$ indicated nonsignificant difference between legibility of white hairs with respect to their exposure time. The copper metal has given 80 to 100 per cent result at 11 to 8 seconds of exposure time. Similar results were observed in brass metal where 80 to 100 per cent legible white hairs were observed at 17 to 8 seconds of exposure time.

The chi-square values were 0.601 and 2.219 for copper and brass metal, respectively in 1218 months category. Overall the minimum and maximum value of frequency (in percentage) of legible white hairs varied from 40 to 80 percent in both metal. In copper metal, the legible white hairs appeared less than 80 percent and were non-significant $\left(\chi^{2}=0.601\right)$. Whereas in brass, the legibility varied from 40 to 80 per cent in spite of having significant difference $\left(\chi^{2}=2.219\right)$ between for all the exposure time (Table 6). 
Above 18 months of age group, the chi square value was 2.414 for both metals. Overall minimum and maximum frequency (in percentage) of animals for white hairs varied from 20 to 60 per cent in both metals (Table 7). The chi square values indicated nonsignificant difference with respect to all the exposure time. In spite of this, the appearance of white hairs in this age group (more than 18 months) was less than 80 percent; hence, legibility may be ambiguous after 18 months of age.

\section{Selection of metal}

In case of score 3, 4 and 5 the developed white brand were for copper $(25,25$ and $15 \%$ animals, respectively) and for brass $(25,10$ and $20 \%$ animals, respectively) in 0-6 months category. At score 5 maximum percentage of instantly recognizable number was observed in brass metal (20 per cent) followed by copper metal (15 per cent) (Table 8). These findings are in agreement with the results reported earlier by Thrift et al., 1971.

In 6-12 months of age group 25, 15, 45 and 15 per cent animals had scored 1,2, 3 and 4, respectively for copper metal. In case of brass metal 20, 20, 45 and 15 per cent animals respectively scored 1,2, 3 and 4. Maximum percentage (45 percent) of animals scored 3 in both metals (Table 8 ) and after score 3 marked reduction in visible white hairs was observed in score 4, as known for better visibility of white hairs. In 12-18 months category copper metal $(45,20,25$ and 10\% animals) and brass metal (45, 20, 30 and 5\% animals) had score of $1,2,3$ and 4 , respectively (Table 8). Overall, 10 percent animals contained visible hairs, when copper metal was used, which is higher that of brass (5 percent) considering score 4 higher visibility was noticed in copper metal than that of brass metals. However, differences among metals were nonsignificant.

Table.1 Different exposure time proposed for different age group

\begin{tabular}{|c|c|c|c|}
\hline & \multicolumn{2}{|c|}{ No. of Animal } & Exposure time \\
\hline \multirow{4}{*}{ 0-6 } & \multirow{4}{*}{20} & 5 & 5 \\
\hline & & 5 & 7 \\
\hline & & 5 & 9 \\
\hline & & 5 & 11 \\
\hline \multirow{4}{*}{ 6-12 } & \multirow{4}{*}{20} & 5 & 8 \\
\hline & & 5 & 11 \\
\hline & & 5 & 14 \\
\hline & & 5 & 17 \\
\hline \multirow{4}{*}{$12-18$} & \multirow{4}{*}{20} & 5 & 12 \\
\hline & & 5 & 15 \\
\hline & & 5 & 18 \\
\hline & & 5 & 21 \\
\hline \multirow{4}{*}{ Above 18} & \multirow{4}{*}{20} & 5 & 17 \\
\hline & & 5 & 20 \\
\hline & & 5 & 23 \\
\hline & & 5 & 26 \\
\hline
\end{tabular}


Table.2 The scoring system

\begin{tabular}{|c|c|}
\hline Score & Interpretation \\
\hline $\mathbf{1}$ & No visible numbers \\
\hline $\mathbf{2}$ & Visible numbers, but illegible. \\
\hline $\mathbf{3}$ & Incomplete numbers, but able to understand. \\
\hline $\mathbf{4}$ & $\begin{array}{c}\text { Easily recognizable numbers, but with breaks or unbranded } \\
\text { areas. }\end{array}$ \\
\hline $\mathbf{5}$ & Instantly recognizable, complete unbroken numbers. \\
\hline
\end{tabular}

Table.3 Mean time for appearance of white hairs using various metals of same dimension in a given exposure time for Sahiwal cattle

\begin{tabular}{|c|c|c|c|}
\hline \multirow{2}{*}{$\begin{array}{c}\text { Age Group } \\
\text { (month) }\end{array}$} & \multirow{2}{*}{$\begin{array}{l}\text { Exposure Time } \\
\text { (Seconds) }\end{array}$} & \multicolumn{2}{|c|}{ Appearance of white hairs (days) } \\
\hline & & Copper & Brass \\
\hline \multirow{4}{*}{0 - 6} & 5 & $45 \pm 6.35$ & $49 \pm 1.83$ \\
\hline & 7 & $43.33 \pm 1.20$ & $50.66 \pm 2.33$ \\
\hline & 9 & $43.4 \pm 4.26$ & $48.75 \pm 3.94$ \\
\hline & 11 & $50.5 \pm 2.10$ & $55.25 \pm 1.75$ \\
\hline \multirow{4}{*}{$6-12$} & 8 & $42.8 \pm 4.93$ & $47.2 \pm 2.4$ \\
\hline & 11 & $46.75 \pm 5.02$ & $49.75 \pm 1.75$ \\
\hline & 14 & $50 \pm 1.15$ & $56.66 \pm 2.40$ \\
\hline & 17 & $58 \pm 2.08$ & $49.66 \pm 3.28$ \\
\hline \multirow{4}{*}{$12-18$} & 12 & $57.66 \pm 1.45$ & $59 \pm 1.00$ \\
\hline & 15 & $60 \pm 2.00$ & $61 \pm 2.65$ \\
\hline & 18 & $58 \pm 4.73$ & $55.5 \pm 6.54$ \\
\hline & 21 & $57.33 \pm 2.33$ & $62.5 \pm 2.50$ \\
\hline \multirow{4}{*}{ Above 18} & 17 & $63.5 \pm 3.5$ & $63 \pm 00$ \\
\hline & 20 & $52.33 \pm 2.03$ & $47 \pm 00$ \\
\hline & 23 & $62 \pm 00$ & $57.66 \pm 2.96$ \\
\hline & 26 & $60 \pm 00$ & $64 \pm 2.00$ \\
\hline
\end{tabular}


Table.4 Mean value of frequency (in percentage) of legible white hairs on the animals in 0 to 6 months age group of Sahiwal cattle

\begin{tabular}{|c|c|c|}
\hline \multirow{2}{*}{$\begin{array}{c}\text { Exposure Time } \\
\text { (Seconds) }\end{array}$} & \multicolumn{2}{|c|}{ Frequency of legible white hairs (percentage) } \\
\cline { 2 - 3 } & Copper (\%) & Brass(\%) \\
\hline $\mathbf{5}$ & 60 & 80 \\
\hline $\mathbf{7}$ & 60 & 60 \\
\hline $\mathbf{9}$ & 100 & 80 \\
\hline $\mathbf{1 1}$ & 80 & 80 \\
\hline Chi square & 2.932 & 0.798 \\
\hline
\end{tabular}

Table.5 Mean value of frequency (in percentage) of legible white hairs on the animals in 6 to 12 months age group of Sahiwal cattle

\begin{tabular}{|c|c|c|}
\hline \multirow{2}{*}{$\begin{array}{c}\text { Exposure Time } \\
\text { (Seconds) }\end{array}$} & \multicolumn{2}{|c|}{ Frequency of legible white hairs (percentage) } \\
\cline { 2 - 3 } & Copper (\%) & Brass (\%) \\
\hline $\mathbf{8}$ & 100 & 100 \\
\hline $\mathbf{1 1}$ & 80 & 80 \\
\hline $\mathbf{1 4}$ & 60 & 60 \\
\hline $\mathbf{1 7}$ & 60 & 80 \\
\hline Chi square & 2.932 & 2.5 \\
\hline
\end{tabular}

Table.6 Mean value of frequency (in percentage) of legible white hairs on the animals in 12 to 18 months age group of Sahiwal cattle

\begin{tabular}{|c|c|c|}
\hline \multirow{2}{*}{$\begin{array}{c}\text { Exposure Time } \\
\text { (Seconds) }\end{array}$} & \multicolumn{2}{|c|}{ Frequency of legible white hairs (percentage) } \\
\cline { 2 - 3 } & Copper (\%) & Brass (\%) \\
\hline $\mathbf{1 2}$ & 60 & 40 \\
\hline $\mathbf{1 5}$ & 40 & 60 \\
\hline $\mathbf{1 8}$ & 60 & 80 \\
\hline $\mathbf{2 1}$ & 60 & 40 \\
\hline Chi square & 0.601 & 2.219 \\
\hline
\end{tabular}


Table.7 Mean value of frequency (in percentage) of legible white hairs on the animals in above 18 months age group of Sahiwal cattle

\begin{tabular}{|c|c|c|}
\hline \multirow{2}{*}{$\begin{array}{c}\text { Exposure } \\
\text { Time } \\
\text { (Seconds) }\end{array}$} & \multicolumn{2}{|c|}{ Frequency of legible white hairs (percentage) } \\
\cline { 2 - 3 } & Copper $(\boldsymbol{\%})$ & Brass (\%) \\
\hline $\mathbf{1 7}$ & 40 & 20 \\
\hline $\mathbf{2 0}$ & 60 & 20 \\
\hline $\mathbf{2 3}$ & 20 & 60 \\
\hline $\mathbf{2 6}$ & 20 & 40 \\
\hline Chi square & 2.414 & 2.414 \\
\hline
\end{tabular}

Table.8 Scores and percentage of animals for both metals

\begin{tabular}{|c|c|c|c|}
\hline \multirow{2}{*}{$\begin{array}{c}\text { Age } \\
\text { Group } \\
\text { (month) }\end{array}$} & \multirow[t]{2}{*}{ Score point } & \multicolumn{2}{|c|}{$\begin{array}{c}\text { Frequency (in percentage) of animals in } \\
\text { different metals }\end{array}$} \\
\hline & & Copper & Brass \\
\hline \multirow{5}{*}{0 - 6} & 1 & 20 & 30 \\
\hline & 2 & 15 & 15 \\
\hline & 3 & 25 & 25 \\
\hline & 4 & 25 & 10 \\
\hline & 5 & 15 & 20 \\
\hline \multirow{5}{*}{$6-12$} & 1 & 25 & 20 \\
\hline & 2 & 15 & 20 \\
\hline & 3 & 45 & 45 \\
\hline & 4 & 15 & 15 \\
\hline & 5 & - & - \\
\hline \multirow{5}{*}{$12-18$} & 1 & 45 & 45 \\
\hline & 2 & 20 & 20 \\
\hline & 3 & 25 & 30 \\
\hline & 4 & 10 & 5 \\
\hline & 5 & - & - \\
\hline \multirow{5}{*}{ Above 18} & 1 & 65 & 65 \\
\hline & 2 & 15 & 15 \\
\hline & 3 & 15 & 20 \\
\hline & 4 & 5 & - \\
\hline & 5 & - & - \\
\hline
\end{tabular}


Table.9 Overall classification of all the animals (in percentage) on the basis of score points for copper and brass metal

\begin{tabular}{|c|c|c|}
\hline \multirow{2}{*}{ Score point } & \multicolumn{2}{|c|}{ Metal } \\
\hline $\mathbf{1}$ & Copper & Brass \\
\hline $\mathbf{2}$ & 38.75 & 40 \\
\hline $\mathbf{3}$ & 16.25 & 17.50 \\
\hline $\mathbf{4}$ & 27.50 & 30 \\
\hline $\mathbf{5}$ & 13.75 & 7.5 \\
\hline
\end{tabular}

Table.10 Mean \pm SE change in Haematological parameters before and after freeze branding in Sahiwal

\begin{tabular}{|c|c|c|c|c|}
\hline S.No. & $\begin{array}{c}\text { Haematological } \\
\text { Parameter }\end{array}$ & $\begin{array}{c}\text { Before } \\
\text { branding }\end{array}$ & $\begin{array}{c}\text { After } \\
\text { branding }\end{array}$ & Significans \\
\hline $\mathbf{1 .}$ & TEC $\left(10^{6} / \mu \mathrm{l}\right)$ & $6.53 \pm 0.33$ & $6.54 \pm 0.22$ & NS \\
\hline $\mathbf{2 .}$ & $\mathrm{Hb}(\mathrm{gm} \%)$ & $8.62 \pm 0.53$ & $8.40 \pm 0.44$ & NS \\
\hline $\mathbf{3 .}$ & $\mathrm{PCV}(\%)$ & $28.20 \pm 2.0$ & $28.60 \pm 1.0$ & NS \\
\hline $\mathbf{4 .}$ & TLC $\left(10^{3} / \mu \mathrm{l}\right)$ & $5.71 \pm 0.45$ & $8.25 \pm 0.6$ & NS \\
\hline $\mathbf{5 .}$ & Neutrophils & $20.28 \pm 1.62$ & $22.62 \pm 2.47$ & $* *$ \\
\hline $\mathbf{6 .}$ & Lymphocytes & $57.42 \pm 2.83$ & $59.54 \pm 2.40$ & $*$ \\
\hline $\mathbf{7 .}$ & Monocytes & $6.26 \pm 0.52$ & $6.42 \pm 0.73$ & $*$ \\
\hline $\mathbf{8 .}$ & Eosinophils & $10.58 \pm 0.99$ & $11.06 \pm 0.80$ & NS \\
\hline $\mathbf{9 .}$ & Basophils & $0.12 \pm 0.10$ & $0.22 \pm 0.13$ & $* *$ \\
\hline
\end{tabular}

Values superscripted by different letters differed significantly from each other in a column $* \mathrm{P}<0.05 * * \mathrm{P}<0.01 \mathrm{NS}=$ non-significant

Fig.1 Frequencies (in percentage) for scores of white hairs for copper and brass

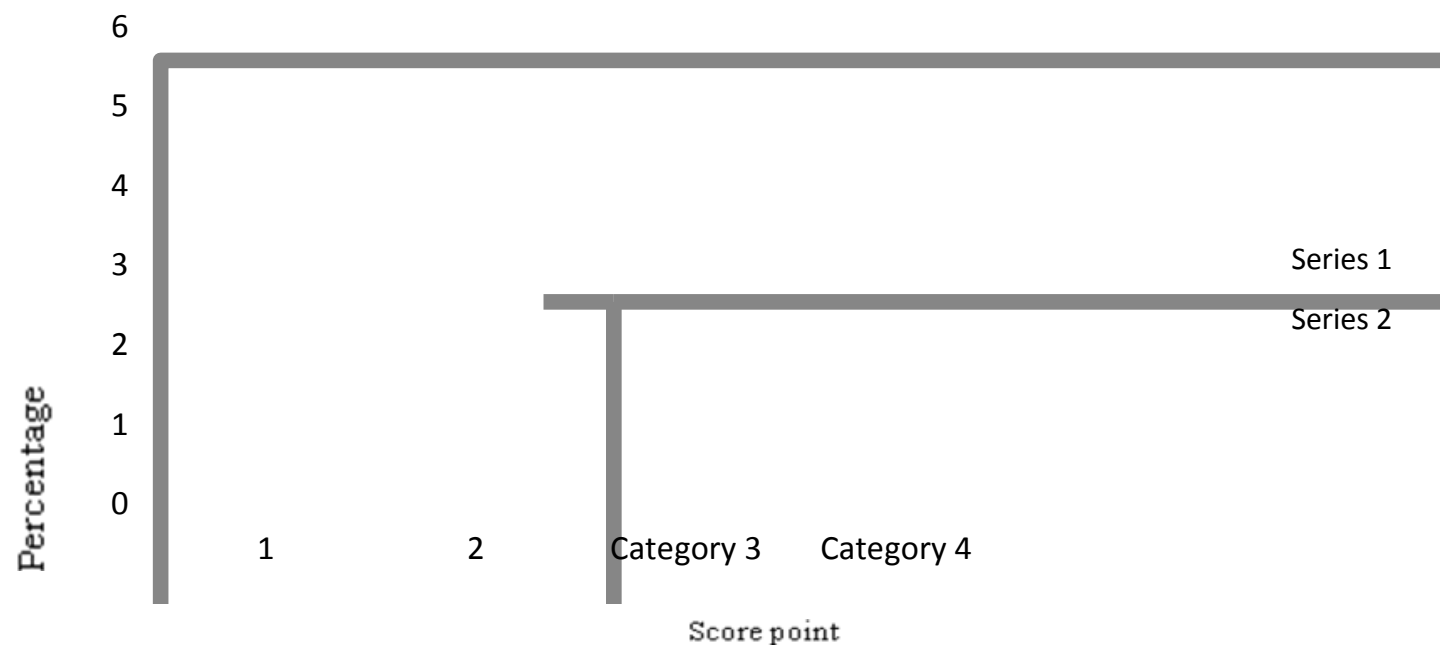


In $12-18$ months of age group, minimum days $(55.5 \pm 6.54)$ required for appearance of white hairs were seen at 18 seconds of exposure time using brass metal. The differences in the time required for appearance of white hairs in all exposure time of above 18 months age groups of copper and brass metal were non-significant.

Overall, age group of 0 to 6 and 6 to 12 , the 100 percent legibility was seen in exposure time 9 (copper) and 8 (copper, brass) seconds of exposure time, respectively. Therefore, copper and brass metal could be recommended for respective age group whereas, age group of 12 to 18 , the 80 percent legibility was seen in exposure time 18 seconds for brass metal. Therefore, brass metal could be recommended (Table 9 and 10).

The weak legibility of white hairs was seen in above 18 months of age group which can be attributed to the thickness of skin of animals which may have become thicker with advancement of age (Hamid et al., 2000). Perhaps increase in weight of metals could have given better legibility of white hairs.

Overall efficiency of brass metal was better than copper metal as 5 per cent animals scored 5 . Hence, it was concluded that brass metal is better.

Farrell (1967) and Torell et al., (2001) who observed that copper to be more efficiently use with more success than brass, steel and aluminium. But in present investigation, brass metal could give better results.

The lymphocytes and monocytes have showed significant rise $(\mathrm{P}<0.05)$ whereas, neutrophils and basophils were also increased significantly $(\mathrm{P}<0.01)$, but above results were within the normal range and could not be an indication of stress associated with freeze branding.

\section{Acknowledgments}

I humbly extend my profound gratitude to my Professors and staff, college of Veterinary science and AH, CGKV, Durg for their constant support and valuable suggestions offered during the course of research work.

\section{References}

Bath, D., Dickinson, F. and Appleman, R.H.A. 1981. Dairy Cattle Principles, Practices, Problems, Profits. $3^{\text {rd }}$ Edition. K. M. Varghese Company, pp. 416-418.

Barragry, T.B. 1994. Veterinary Drug Therapy. Lea and Febiger, Philadelphia, pp 59-60.

Bertram, J., Gill, B. and Coventry, J. 2006. Freeze branding. Agnote Animal Production, alice Springs J., 15: 1-5.

Farrell, R.K., Koger, L.M. and Winward, L.D. 1966. Freeze branding of cattle, dogs and cats for identification. J. Am. Vet. Med. Assoc., 149: 745-752.

Hall, J.B., Greiner, S.P. and Gregg, C. 2004. 'Cattle identification: Freeze branding'., 400-301.

Hamid, M.A., Husain, S.M.I., Khan, M.K.I., Islam, M.N. and Biswas, M.A.A. 2000. Skin thickness in relation to milk production of crossbred cows. Pakistan J. Biological Sci., 3(9): 15251529.

Hooven, N.W.Jr. and Hollon, B.F. 1971. Freeze branding on unclipped areas. $J$. Dairy Sci., 54(5): 785(Abstr.).

Keys, J.E., Hooven, N.W., Weinland, B.T. and Miller, R.H. 1977. Effect of anatomical site, exposure time, age, refrigerant and breed on legibility of freeze marks on dairy cattle. J. Dairy Sci., 60(7): 1163-1168.

Lay, D.C., Friend, T.H., Randel, R.D., Bowers, C.L., Grissom, K.K. and Genkins, O.C. 1992. Behavioral and 
physiological effects of freeze or hot iron branding in crossbred cattle. $J$. Anim. Sci., 70: 330-336.

Lay, D.C.F., Randel, R.D., Bowers, C.L. and Grissom, K.K. 1990. Effect of freeze or hot iron branding of CB cattle on some physiological indicators of stress. J. of Anim. Sci., Abstract 68 (Suppl. 1). McMahon, C.R., Burton, H.R., VanDenHoff, J., Woods, R. and Bradshaw, C.J. 2006. Assessing hot-iron and cryobranding for permanently marking southern elephant seals. J. Wildl. Management, 70: 1484-1489.

Mishra, S., Roy, S., Bhonsle, D. and Chourasia, S.K. 2005. Determination of exposure time for freeze branding in sahiwal breed. J. Agri., 10(1): 13-19.

Potter, G. 1966. Branding and The leather industry. Proc. Freeze Brand Seminar, Washington State University.

Schwartzkopf-Genswein, K.S., Stookey, J.M., and Welford, R. 1997. Behavior of cattle during hot iron and freeze branding and the effects on subsequent handling ease. J. Anim. Sci., 75: 20642072.
Sherwin, R.E., Haymond, S., Stricklan, D. and Olsen, R. 2002. Freeze branding to permanently mark bats. Wildlife Society Bulletin, 30(1): 97-100.

Snedecor, G.W. and Cochran, W.G. 1994. Statistical methods. $8^{\text {th }}$ edition. Iowa State University Press, Iowa, USA.

Steel, R.G.D. and Torrie, J.H. 1984. Principles and procedures of statistics, A Biometrical approach. $2^{\text {nd }}$ edition. McGraw - Hill International Book Company.

Thrift, F.A. and Absher, C.W. 1971. Freeze branding versus fire branding as methods of beef cattle identification. $J$. Range Manage., 24(1): 75-78.

Torell, R., and Riggs, W.N. 2001. Freeze Branding Ranch Animals. University of Nevada Cooperative Extension, Fact Sheet 01-25.

Wagner, R.W., Helmondoller, R., and Pritchard, J. 2000. Beef cattle. Extension Service. West Virginia University.

Whittier, J.C. and Ross, E.J. 1993. Agricultural publication GO2202Reviewed.

\section{How to cite this article:}

Arvind K. Nandanwar, Sharad Mishra and Deepak Thakur. 2019. Studies on Exposure Time for Freeze Branding using Copper and Brass Metal in Sahiwal Cattle. Int.J.Curr.Microbiol.App.Sci. 8(12): 177-186. doi: https://doi.org/10.20546/ijcmas.2019.812.026 